\begin{abstract}
Iranica
Abstracta Iranica Revue bibliographique pour le domaine irano-aryen

Volume 34-35-36 | 2017

Comptes rendus des publications de 2011-2013
\end{abstract}

\title{
J. Elayi, A. G. Elayi. The first Series of the Coinage of Arwad
}

\section{Astrid Nunn}

\section{(2) OpenEdition}

1 Journals

\section{Édition électronique}

URL : http://journals.openedition.org/abstractairanica/41218

DOI : 10.4000/abstractairanica.41218

ISSN : 1961-960X

Éditeur :

CNRS (UMR 7528 Mondes iraniens et indiens), Éditions de l'IFRI

Référence électronique

Astrid Nunn, « J. Elayi, A. G. Elayi. The first Series of the Coinage of Arwad », Abstracta Iranica [En ligne], Volume 34-35-36 | 2017, document 99, mis en ligne le 15 juillet 2016, consulté le 27 septembre 2020. URL : http://journals.openedition.org/abstractairanica/41218; DOI : https://doi.org/10.4000/ abstractairanica. 41218

Ce document a été généré automatiquement le 27 septembre 2020.

Tous droits réservés 


\title{
J. Elayi, A. G. Elayi. The first Series of the Coinage of Arwad
}

\author{
Astrid Nunn
}

\section{RÉFÉRENCE}

J. Elayi, A. G. Elayi. « The first Series of the Coinage of Arwad ». Trans., 43, 2013, p. 11-26.

1 Faisant suite aux remarques plus générales publiées dans le vol. Trans. 42, les AA. traitent ici la première série de monnaies d'Arwad qui sont des tiers de sicles en argent. Celle-ci débute vers 425 av. J.-C., plus tardivement que dans les autres trois grandes cités phéniciennes Byblos, Tyr et Sidon. 61 exemples sont présentés sous forme de catalogue. On y voit au droit une divinité au torse humain se terminant en une queue de « sirène » (ichtyomorphe) et tenant deux dauphins et, au revers, une galère aspectée de droite.

\section{AUTEURS}

\section{ASTRID NUNN}

Université de Munich 